\title{
Is Multiculturalism Discriminatory?
}

\author{
Bouke de Vries ${ }^{1}$ (I)
}

Published online: 20 June 2019

(c) The Author(s) 2019

\begin{abstract}
Many political theorists are multiculturalists. They believe that states ought to support and accommodate minority cultures, even if they disagree about when such support and accommodations are due and what forms they should take. In this contribution, I argue that multiculturalists have failed to notice an important objection against a wide range of multiculturalism policies. This objection is predicated on the notion that when states support and accommodate minority cultures, they should support and accommodate many subcultures and individualistic conceptions of the good as well. However, since a significant proportion of multiculturalism policies imposes financial costs on society, it will often be prohibitively expensive for states to support and accommodate citizens' subcultures and individualistic conceptions of the good on an equal basis. The result is that implementing such policies is likely to end up discriminating against certain groups, which might include e.g. fervent football fans, globe-trotters, mountain climbers, motor bikers, Hippies, and artists. I conclude by considering six reasons for giving preferential treatment to minority cultures that would allow multiculturalists to avoid this implication, which invoke, inter alia, the depth, duration, and involuntariness of cultural commitments; the role of culture in allowing people to live autonomously; and cultural rights to political self-determination. None are found to be convincing.
\end{abstract}

Keywords Multiculturalism · Minority rights · Discrimination · Majority cultures · Subcultures · Will Kymlicka

\section{Introduction}

Multiculturalism is the doctrine that states should not merely allow cultural diversity to exist (construed broadly to include religious diversity) as is required by liberaldemocratic rights to freedom of association, conscience, religion, and speech. They should also support and accommodate cultural groups when, and because, these

Bouke de Vries

bouke.devries@umu.se

1 Department of Historical, Philosophical and Religious Studies, Umeå University, Umeå, Sweden 
groups are disadvantaged relative to other cultural groups within society, which might be because they find it more difficult to survive or flourish and/or because they derive fewer advantages from state policies. (I shall henceforth refer to policies that offer such support and accommodations as 'multiculturalism policies'.) Since minority cultures are more likely to satisfy these criteria than majority cultures, theories of multiculturalism have focused mostly on when and how states should support and accommodate minority cultures, ${ }^{1}$ and so will I within this contribution.

Whereas support for multiculturalism is widespread among scholars (e.g. Kymlicka 1995; Modood 2013; Parekh 2006; Patten 2014; Shachar 2001; Taylor 1994), this contribution seeks to strengthen the anti-multiculturalist case by raising a novel objection against a wide range of multiculturalism policies. This objection is predicated on the notion that when states support and accommodate minority cultures, they should support and accommodate many subcultures and individualistic conceptions of the good as well. However, since a significant proportion of multiculturalism policies imposes financial costs on society, it will often be prohibitively expensive for states to support and accommodate citizens' subcultures and individualistic conceptions of the good on an equal basis. The result is that implementing such policies is likely to end up discriminating against certain groups, which might include e.g. fervent football fans, globe-trotters, mountain climbers, motor bikers, Hippies, and artists. I conclude by considering six reasons for giving preferential treatment to minority cultures that would allow multiculturalists to avoid this implication, which invoke, inter alia, the depth, duration, and involuntariness of cultural commitments; the role of culture in allowing people to live autonomously; and cultural rights to political self-determination. None are found to be convincing.

\section{Multiculturalism Policies}

Before looking at the discrimination objection in more detail, we need to get greater clarity on what multiculturalism policies are and when they are believed to be due by those who defend them. I have defined multiculturalism policies as policies that assist and accommodate cultural groups (construed broadly to include religious groups) when, and because, these groups are disadvantaged relative to other cultural groups within society, which might be because they find it more difficult to survive or flourish and/or because they derive fewer advantages from state policies. Examples of such policies include, but are not limited to, subsidies for cultural festivals and community centres; special legal rights for linguistic minorities (think of the right of the Quebecois to require companies with 50 or more employees to use French as the primary language of communication); legal exemptions for minority religions (think of the right of the Amish to pull their children out of school before the legal age); and political self-determination rights for historical minorities and indigenous groups (think of the right of Native-American tribes to govern themselves on their reservations).

\footnotetext{
${ }^{1}$ But see Orgad (2015) for a defence of majority culture rights.
} 
To avoid confusion, it bears emphasis that state policies only qualify as multiculturalist when they have the aim of helping members of the disadvantaged cultures live in accordance with their culture. ${ }^{2}$ This means that not all policies that bestow benefits on disadvantaged cultures-which, as was mentioned, are usually those of minorities, which is why my focus will be on minority cultures from hereon-fall under the header of multiculturalism policies, as some of these policies do so without seeking to promote people's cultures as such. (Another way of making this point is to say that the cultural benefits that they bestow are a side effect.) Without trying to provide an exhaustive list, one might think of policies with the following aims:

Providing universal services: Such policies make generic goods available to cultural and non-cultural groups alike, such as police services and fire-protection. Since the provision of these goods is not meant to promote the interests of (minority) cultures specifically, policies that fall into this category are not plausibly conceived of as multiculturalism policies. (cf. Patten 2014, p. 121) Securing the fair value of rights: Whilst such policies do offer tailored support to minority cultures, they do so in order to help their members exercise their legal rights rather than to support or accommodate their cultures as such. To ensure a fair trial, for instance, the proceedings of a court might be translated into a minority language when the accused's grasp of the majority language is poor.

Respecting historical agreements: Such policies support and accommodate minority cultures when, and because, this is necessary for honouring agreements that these groups made with the state. An example may be found in the educational exemptions that Canada has granted to the Hutterites for populating the western frontier (cf. Kymlicka 1995, pp. 116-120). As with the previous categories, one need not be a multiculturalist in order to endorse such policies; all that is necessary is that one believes that pacta sunt servanda.

Rectifying injustice: Such policies support and accommodate minority cultures when, and because, this helps to rectify injustices that these groups have suffered at the state's hands (and might in some cases continue to do so). For example, a state might grant local political autonomy to minority cultures that have been oppressed by it for a significant period, such as Native-Americans in the United States and Catalans in Spain. To support this, one again does not need to be a multiculturalist; all that is required is that one deems it pertinent that injustices be remedied.

Avoiding evils: Such policies support and accommodate minority cultures on pragmatic grounds. For example, a Western state might allow an East-African community to engage in a modest form of female genitalia cutting in order to ensure that it occurs under proper medical supervision rather than unsupervised in private with significantly greater health risks (cf. Levy 2000). Another example is when a state grants local political autonomy to a minority culture in order to prevent its members from causing (further) social unrest. Since states

\footnotetext{
${ }^{2}$ Which does not mean, of course, that this must be their only aim.
} 
do not seek to promote specific cultures in such cases but rather to avoid certain evils, these kinds of policies are not plausibly construed as multiculturalism policies either.

There are broadly two (mutually compatible) views on when multiculturalism policies are due, and, correspondingly two versions of multiculturalism. On the first version, multiculturalism policies are due when state policies confer special benefits on majority cultures (whether intentionally or unintentionally) in order to rectify the resulting cultural inequalities (Kymlicka 1995, pp. 107-115; Modood 2013, pp. 34-79; Patten 2014, pp. 149-185). Whilst this defence of multiculturalism policies is conditional upon states creating cultural inequalities in the first place, proponents of the current version correctly believe that this is often impossible to avoid. Within societies with high levels of linguistic diversity, for instance, state organisations will usually be able to operate in a limited number of languages only; since these will need to be languages that large sections of their populations speak to allow for effective communication, some cultures within these societies are bound to receive greater benefits than others. And even when it is possible to implement policies that do not suit any cultural group, some multiculturalists maintain that there are reasons of beneficence for desisting from this. For example, even when a state can pick a national day of rest that is not amenable to any religion within society, Patten (2014, p. 170) has argued that there are good grounds for accommodating the preferred day of some religion to make it easier for its adherents to worship.

The compensation that states provide for the cultural biases of their policies might either take a pro-rated or welfarist form. Under a pro-rated scheme, the benefits that multiculturalism policies bestow on minority cultures should have the same per capita value as the special benefits that state policies confer on majority culture (for a defence of this view, see Patten 2014). This allows for the possibility that citizens with different cultures will benefit from per capita equal support to unequal degrees. Such differences might arise, for instance, when the number or spread of individuals with the same culture is such that only some cultural groups will enjoy economies of scale or be able to afford certain lumpy goods. Under a welfarist scheme, in contrast, states will try to reduce at least some of these inequalities, which means that they may end up giving goods to minority cultures that are worth more than the per capita value of the benefits that their policies conferred on majority cultures (for defences of this view, see e.g. Réaume 2017, p. 69; De Schutter 2017, pp. 77-78; Pierik and Van Der Burg 2014, p. 501). For example, when a state subsidises the publication of books within the majority language and seeks to compensate a small linguistic minority for this by subsidising the publication of books in its language, then given that the publication of books tends to become cheaper the more of them are ordered, the linguistic minority might be given subsidy with a greater per capita value so that the money granted will be equally useful to its members.

On the second version, multiculturalism policies are due simply when it is more difficult for minority cultures to survive or flourish than it is for majority cultures, at least when these cultures are not hostile to liberal democracy (for defences of this view, see e.g. Cohen 1999; Lippert-Rasmussen 2017). What this means is that minority cultures might have claims to state support and accommodations regardless 
of whether the fact that it is harder for them to survive or flourish is (partially) due to majority biases of state policies. (To avoid confusion, notice that proponents of this version of multiculturalism are not committed to the view that states ought to guarantee the survival and flourishing of any minority culture; insofar as offering such guarantees is possible at all, they might believe that this would be too expensive, require too much coercion, and/or assign too little responsibility to people for the fate of their own culture.)

\section{The Discrimination Objection}

Having clarified the notion of multiculturalism policies and considered when such policies are believed to be due, my aim in this section is to propose a novel objection against a wide range of multiculturalism policies. In so doing, I do not mean to suggest that this the only compelling objection against multiculturalism. For reasons of space, I will not be able to go into the objections raised by authors such as Barry (2002, pp. 34-35); Kukathas (2012, pp. 40-41), and Scheffler (2007, p. 107), though I believe that there is some truth to their critiques.

According to the objection that I want to raise here, many multiculturalism policies discriminate against citizens ${ }^{3}$ whose conceptions of the good are not tied to participation within a specific cultural community, or at least not the types of communities that multiculturalists seek to support and accommodate. Examples include, but are not limited to, conceptions of the good that revolve around globe-trotting, mountain climbing, sailing, rock music, body-building, motor biking, hunting, producing abstract art, participating in Deadhead, Goth, and Hippy communities, supporting a particular football team, practising and promoting Effective Altruism, playing and collecting board-games, competing in marathons, and doing yoga. Some of these activities might be part of specific subcultures - think, for instance, of communities of runners, body-builders, motor biking, Goths, Hippies, and hunters in some places - and I will refer to conceptions of the good that are structured around such cultures as 'subcultural conceptions of the good'. However, these are not the types of cultures that can count on state support and accommodations under theories of multiculturalism, which are normally confined to the cultures of national minorities (e.g. the Quebecois, Frisians, Catalans, Scots); indigenous communities (e.g. the Pueblo, Nunavut, Sami, Aboriginals), and groups of immigrants (e.g. Muslim and Hindu immigrants in Western Europe). Another category of conceptions of the good that does not qualify for state support and accommodations under theories of multiculturalism are those that I term 'individualistic'. Individualistic conceptions are not structured around participation in the traditions and practices of a (sub)cultural community, but rather around activities in which the holders engage more or less by themselves. Paradigmatic examples include the conceptions of the good of hermits and lone artists. However, they may also revolve around activities that are part of

\footnotetext{
3 The same might be true of groups of non-citizens. For the purposes of this contribution, my focus will be on citizens.
} 
certain subcultures yet in which the relevant agents engage (largely) independently, such as motor-biking, running, and sailing.

The objection that a significant share of multiculturalism policies discriminates against citizens with subcultural and individualistic conceptions of the good might be formulated as follows:

(1) Many multiculturalism policies support and accommodate minority cultures in ways that impose (net) financial costs on societies.

(2) A large proportion of citizens with subcultural and individualistic conceptions of the good have claims to state support and accommodations that are at least as strong as the claims of citizens with cultural conceptions of the good.

(3) When a state $\mathrm{S}$ grants a specific good to a group $\mathrm{A}$, then insofar as another group $\mathrm{B}$ has at least as strong a claim to a similar good, then $\mathrm{S}$ should grant that good to $\mathrm{B}$.

(4) Because of (2) and (3), states that implement costly multiculturalism policies should also support and accommodate a large proportion of citizens with subcultural and individualistic conceptions of the good even when this is costly.

(5) Extending costly support and accommodations to these individuals is bound to be prohibitively expensive.

Therefore

(6) The implementation of many multiculturalism policies ends up discriminating against citizens with subcultural and individualistic conceptions of the good.

I believe that (2) is the most controversial premise. Before vindicating it within the next section, I want to comment on some of the other premises.

Multiculturalism policies (construed broadly to include the accommodation of cultural diversity through the design of politico-legal institutions) that are likely to impose net financial costs on society include, inter alia, public subsidies for endangered minority languages, ethnic minority festivals, the construction of places of worship for minority religions, and the provision of Halal or Kosher food within predominantly secular or Christian societies. However, they might also include state recognition of cultural self-government rights when devolution raises bureaucratic costs, as well as cultural/religious exemptions from laws when the exempted are not required, or simply not able, to fully absorb the costs of their exemptions. For example, Sikhs who are exempted from motor helmet laws may not be able to fully cover the costs of any aggravated head injuries that they sustain as a result of not wearing a helmet when driving.

Most multiculturalists believe that, at least up to a point, it is fair for societies to bear these kinds of costs. The reason why they seem to believe that it is fair towards members of minority cultures is that these individuals are presumed to benefit from multiculturalism policies, whereas the reason why they seem to believe that it is fair towards members of majority cultures is that the cultures of these individuals enjoy certain advantages that minority cultures lack (as we have seen in 'Multiculturalism 
Policies' section, these might consist of the fact that state policies confer greater benefits on them and/or of the fact that it is easier for them to survive or flourish). Insofar as societies can be divided into majority and minority cultures without remainder-as multiculturalists also seem to assume-this would suggest that no one is treated unfairly by the financial costs of multiculturalism policies.

Suppose arguendo that contemporary societies, or at least contemporary liberal democracies on which I focus within this contribution, can indeed be divided into majority and minority cultures without remainder. A problem remains in that case, namely that not all members of majority and minority cultures place much value upon their culture's traditions and practices and instead hold what I have termed subcultural or individualistic conceptions of the good. Since these individuals have equally legitimate interests in living self-directed lives, forcing them to bear the costs of multiculturalism policies appears unfair.

To make the problem more concrete, consider the subsidies that the Dutch government provides for the publication of books in Frisian, a language spoken by an ethnic minority within the north of the Netherlands. Given that virtually all Frisian speakers are fluent in Dutch (and therefore do not need access to Frisian books in order to quench their reading thirst), the question arises how it can be fair to force non-Frisian taxpayers to help fund these subsidies when they care very little, if at all, about the preservation of the Frisian language and Frisian culture more generally (as is the case for a substantial share). Similarly, we need to know how it can be fair to force Frisians who are (largely) indifferent to the preservation of their language and culture more broadly to help pay for these subsidies. After all, insofar as these groups are not required to make these expenses, they might be able to spend the money that is saved on their own conceptions of the good. Alternatively, the Dutch government might invest the money in various public goods, such as healthcare and infrastructure, which would benefit them as well.

Some multiculturalists might say that subsidising the publication of Frisian books is fair because the Dutch government also subsidises Dutch literature, movies, and music (and even if this were not the case, the mere fact that it is easier for Dutch culture to survive and flourish might be considered an adequate justification by some of them). The problem with this response is that a significant proportion of Frisian and non-Frisian taxpayers who care little, if at all about Frisian literature also care little, if at all about Dutch literature, movies, and music, or, indeed, the various traditions and practices associated with Dutch culture more generally. For this to be the case, they need not actively dislike these traditions and practices (e.g. they need not consider the Saint Nicholas tradition with its controversial character of Black Pete racist, oppose the monarchy, or find football and ice-skating abhorrent), though some might. It suffices that compared to the activities that are central to their subcultural or individualistic conceptions of the good-e.g. globe-trotting, mountain climbing, sailing, rock music, body-building, motor biking, producing abstract art-the relevant cultural traditions and practices simply play no significant role within their lives.

In response, multiculturalists might accept the problem but argue that using public money to support and accommodate cultural conceptions of the good ceases to be unfair when states support and accommodate non-cultural conceptions of the 
good under similar conditions. Though such levelling-up would avoid the unfairness charge, I believe that on each of the two major accounts of when multiculturalism policies are due (see 'Multiculturalism Policies' section), extending such support and accommodations will be prohibitively expensive. Consider first the version of multiculturalism that requires the state to help minority cultures survive or flourish irrespective of whether it is responsible for the facts that these cultures find it more difficult to survive or flourish than majority cultures. Even if we accept a less demanding variation on this view, according to which costly state support and accommodations are due only when minority cultures struggle to survive, it is doubtful whether similar support and accommodations can be granted to all those citizens who struggle to live in accordance with their tolerable subcultural and individualistic conceptions of the good. The reason for this is that a great many citizens with such conceptions of the good find themselves in this situation. Just think of those who can barely fund their passion for globe-trotting, mountain climbing, or sailing (all of which are very expensive activities), or of those who simply lack enough like-minded individuals within their region to engage in activities that are central to their conceptions of the good (this might be the predicament of fervent football players within parts of the US and of fervent American football players within parts of Europe).

Things do not get much better on the other version of multiculturalism, according to which multiculturalism policies are due when state policies confer special benefits on majority cultures in order to rectify the resulting cultural inequalities. The first thing to note here is that whether the pro-rated or welfarist interpretation of this view is accepted, states will already incur significant costs in order to compensate minority cultures for the (in many cases inevitable) ways in which state policies favour majority cultures, as discussed within 'Multiculturalism Policies' section. However, when subcultures and individualistic conceptions of the good ought to be compensated as well-imagine that as compensation for subsidising Dutch literature, the Dutch government does not only have to subsidise Frisian literature, but also globe-trotting, mountain climbing, sailing, and numerous other tolerable activities that are central to at least some citizens' conceptions of the good-the costs are likely to be excessive.

The same is true when instead of compensating subcultures and individualistic conceptions of the good for special benefits that state policies bestow on majority cultures, states compensate them for any special benefits that their policies confer on other subcultures and individualistic conceptions. This might mean, for instance, that when a local government constructs a skateboard park, football players, basketball players, tennis players, squash players, and those with passions for various other sports will need to be compensated (this is in fact Patten's (2014, p. 122) view, who suggests that such a government should also build ice rinks, squash halls, and so on). Likewise, when a state decides to build a new art museum, opera-lovers, balletlovers, etc. might be owed compensation for this. The problem with this approach is that given how diverse contemporary liberal democracies are, most policies that states might implement are likely to bestow unequal benefits on citizens' different cultures, subcultures, or individualistic conceptions of the good, such that compensation will be due in a huge number of cases. (An even more ambitious and therefore unrealistic approach requires states to compensate all tolerable conceptions of the 
good within society for special benefits that are bestowed upon any other conception of the good within society; for further discussion of the problems with such an approach, see Martin 2017, p. 158.)

\section{Can a Cultural Exceptionialism be Vindicated?}

If the foregoing is correct, then costly multiculturalism policies can be justified only when there are reasons for supporting and accommodating members of minority cultures with cultural conceptions of the good that do not similarly require states to support and accommodate most citizens with tolerable subcultural and individualistic conceptions of the good. Absent such reasons, it appears that implementing costly multiculturalism policies will end up discriminating against the latter because of the financial unfeasibility of granting them similar support and accommodations. This final section considers six potential differences that might justify such a 'cultural exceptionalism'. Whereas space constraints prevent me from discussing each would-be difference in detail, I hope to say enough about them to show that there are good grounds for doubting their ability to disarm the discrimination objection.

A first would-be difference is that the cultural commitments of citizens with cultural conceptions of the good are more important to their lives than the subcultural and individualistic commitments of citizens with subcultural and individualistic conceptions of the good are to theirs. This might be due to the fact that cultural commitments are deeper (i.e. more central to people's identities and life goals) and/or that they last longer than subcultural and individualistic ones.

Even if this is true in some cases, there seem to be many counter-examples where people's subcultural and individualistic commitments are every bit as important to their lives as the cultural (including religious) commitments of other people are to theirs. To mention just a few, Martin (2017, p. 152) has rightly noted that many football supporters 'believe that they have a strong obligation to support a given team, such that it becomes virtually ritualistic, and in spite of constraints from work, family and so on'. Similarly, for a large share of artists, producing art is the one of the main purposes of their existence as evinced by the fact that many are willing to live on a subsistence level to be able to do so, just as running, motor biking, and mountain climbing are not merely hobbies for various groups of individuals but a deep source of meaning and major component of their identity (indeed, in the case of mountain climbing, it is something that some are willing to run the risk of dying for). And whilst it is true that some subcultural and individualistic commitments tend to be relatively short-lived, such as identification with the Goth subculture, many others-including the ones just mentioned_often last for most of people's lives.

A second would-be difference has been suggested by Kymlicka, who has argued that access to a stable cultural community is necessary for people to live autonomously by providing them with a meaningful range of lifestyle options (1991, pp. 165-166). I believe that there are two problems with this view. One is that it leaves unclear why it would be wrong to use the money spent on multiculturalism policies in order to help members of minority cultures integrate or assimilate into the 
majority culture, which would also secure a meaningful range of lifestyle options for them if successful (and possibly a wider range, especially when the relevant minority cultures are more illiberal than the majority culture). Indeed, since such an integrationist/assimilationist approach will usually be cheaper than supporting and accommodating struggling minority cultures, it has the advantage that it imposes fewer costs on society. Another problem is that access to specific cultural communities does not seem necessary for an autonomous life. Lives devoted to, inter alia, sailing, globe-trotting, mountain climbing, rock music, body-building, motor biking, producing abstract art, supporting a particular football team, and practising and promoting Effective Altruism can all be perfectly self-directed, it seems, even though none of these activities are tied to membership of a specific cultural community (cf. Waldron 1991), or at least not the types of communities that multiculturalists seek to support and accommodate.

A third would-be difference is that cultural conceptions of the good are usually involuntarily acquired whereas subcultural and individualistic ones are not. Insofar as agents bear greater moral responsibility for the costs of voluntarily acquired conceptions of the good than for the costs of those that were not voluntarily acquired (as luck-egalitarians would contend), this would suggest that refusing costly state support and accommodations to (most) citizens with subcultural and individualistic of the good may be justifiable. However, the empirical premise of this argument is dubious. Not only do people sometimes deliberately seek to develop a specific cultural or religious conception of the good (which might involve them joining another cultural or religious group), many of us had our passion for football, mountain climbing, motor biking, rock music, abstract art, and so on instilled in us by our parents or by our wider social milieu.

A fourth would-be difference is that when citizens' cultural conceptions of the good are not supported and accommodated by the state, they are more likely to experience diminutions in their self-respect than when citizens with subcultural and individualistic conceptions are denied support and accommodations. Whilst this might be correct, e.g. Kramer (2017, pp. 324-325) has plausibly argued that what contributes to the goodness of people's lives is warranted self-respect rather than sheer self-respect. This helps to explain why, for instance, the fact that a racist's self-respect might be diminished when her government grants equal rights to a hitherto oppressed racialised group seems to carry no moral weight. Yet if what matters morally is warranted self-respect rather than sheer self-respect, then it still needs to be shown that members of minority cultures would be justified in experiencing (greater) losses of self-respect.

A fifth would-be difference applies exclusively to minority cultures with their own language. It says that states should facilitate the use of minority languages in parliament and provide public services within the relevant languages despite the costs that this imposes, for if this is not done, the relevant speakers will have reduced access to their political, social, and civil rights.

Two replies are in order. First, given that the aim of such accommodations is to secure access to rights rather than promote minority cultures as such, I have suggested in 'Multiculturalism Policies' section that they are not plausibly conceived of as multiculturalism policies. However, even if they are classified as such-and this 
brings me to the second point - they will be due in a limited set of cases only. To the extent that members of linguistic minorities are fluent within the majority language (assuming that this is the language of the public sector, which is usually the case), such as Frisians within the Netherlands, they will have no claims to having their language accommodated based on the current rationale. But that is not all; insofar as eliminating linguistic barriers to the exercise of people's rights is what matters, there is another way in which states might realise this than through multi-lingual accommodations. They can take measures to ensure that younger generations of linguistics minorities all become fluent within the majority language, which would allow them to abolish the relevant multi-lingual accommodations within the future. Indeed, since such a strategy is cheaper than accommodating minority cultures in perpetuum, it has an important advantage over its multiculturalist contender.

A final would-be difference is predicated on the notion that cultural communities have moral rights to political self-determination that other groups lack, including various subcultures. To honour these rights, the argument goes, states should allow minority cultures to govern themselves politically even if this raises bureaucratic costs. In addition to this, they might have a duty to (financially) support these cultures when this helps to create conditions under which political self-determination becomes easier for them, the assumption being that the stronger the cultural ties among individuals, the more likely it is that they will be willing and able to (continue to) govern themselves politically. (For defences of multiculturalism policies along these lines, see e.g. Bauböck 2017; Kymlicka 2018.)

Since this argument for multiculturalism policies is conditional upon minority cultures having moral rights to political determination, it seems that, if sound, it can only justify political recognition of, and public support for, national minorities (think of the Quebecois and Catalans) and indigenous groups (think of the Pueblo and Nunavut). Were cultural communities of recent immigrants to have moral rights to political self-determination as well, this would render it morally permissible for people to colonise another state's territory, which I take to be a reductio even if the self-government rights to which they would be entitled would not allow them to secede unilaterally from the host country (cf. Bauböck 2017, pp. 18-19; Kymlicka 2018, p. 85).

Yet even for national minorities and indigenous groups, I believe that cultural rights to political self-determination cannot ground entitlements to costly multiculturalism policies. If, as I assume, the function of rights is to protect the interests of the right-holders ( $\operatorname{Raz} 1988$ ), then the costs that such policies impose on societies must be justified that the interests that members of minority cultures have in political self-determination. What might these be? The most plausible answer, it seems, is that being part of a politically self-governing cultural community promotes the personal autonomy and well-being of some of their members. However, we have seen that the same is true of, inter alia, sailing, mountain climbing, motor-biking, bodybuilding, producing abstract art, supporting a particular football team, and practising and promoting Effective Altruism for individuals with subcultural- and individualistic conceptions of the good (some of whom, it bears mentioning, might be part of the same minority cultures). These activities are often at least as important to their personal autonomy and well-being as political self-determination is to the personal autonomy and well-being of those with cultural conceptions of the good. But if this 
true, then given that citizens with subcultural- and individualistic conceptions of the good have equally legitimate interests in pursuing their conceptions, forcing them to subsidise the latter's wish to be part of a politically self-governing cultural community fails to respect their moral status.

The following objection might be raised at this point: If cultural communities-including majority cultures and society-wide cultures that encompass multiple smaller cultures-have no moral right to political self-determination when this imposes net costs on society, by which I mean that more public money must be spent to realise the goals of justice and stability as well compared to a situation where the relevant communities lack political autonomy, then there seems nothing wrong for two countries to fuse against the will of their populations when this allows these goals to be met better, perhaps because of the economies of scale that are realised thus. In fact, it might even justify annexation of (part of) another state's territory.

My response is that we do not need to postulate cultural rights to political selfdetermination in order to explain why such fusions and annexations will generally be unjustifiable. There is another, more plausible explanation. This is that fusing countries against the will of their populations and annexing foreign territory is likely to have unacceptable costs in terms of justice and stability, apart from the fact that these things might violate people's democratic rights (even when individuals are not entitled to political autonomy for their respective cultural communities, they might still have a moral right to decide about changes to the political entities of which they are part; whether this is so I leave for the reader to decide). Indeed, even when the relevant fusions and annexations could achieve the goals of justice and stability better in the long term, the consternation and possible bloodshed that they are likely to cause in the short term will usually act as a side-constraint on their permissibility.

\section{Conclusion}

It appears, then, that there are no differences between cultural conceptions of the good and subcultural and individualistic ones that justify granting financially costly support and accommodations to the former but not to (most of) the latter. Yet if this is correct, then implementing costly multiculturalism policies is likely to end up discriminating against citizens with subcultural and individualistic conceptions of the good because of the financial unfeasibility of extending similar benefits to them.

I want to end with three comments. The first is that these problems of generalisability are not unique to multiculturalism policies that impose financial costs on society. They also plague at least some multiculturalism policies that impose libertycosts on society (possibly in addition to any financial costs that might be imposed). Consider again the Quebecois law that requires companies with 50 or more employees to use French as the primary language of communication; were governments to pass similar laws to protect activities that are central to citizens' subcultural and individualistic conceptions of the good, the overall effects are likely to be deeply illiberal. Just imagine a state that required the users of public sports facilities to engage in sports that struggled to survive, along with requiring public radio stations to play music genres that were threatened with extinction; requiring public museums 
to display endangered art genres; requiring company canteens to serve locally shot wildlife in order to support dying hunting scenes, and so on.

Having said that, and this brings me to the second point, I do not mean to suggest that states should never implement costly policies that benefit minority cultures. They may have a duty to do so when this promotes justice and/or stability, and I have outlined several conditions in 'Multiculturalism Policies' section under which this is likely to be the case-e.g. when it helps to secure access to rights; when it is necessary for honouring historical agreements; when it helps to rectify injustice. What is important for us is that this does not vindicate multiculturalism, as the reason for supporting and accommodating minority cultures in such cases is instrumental, namely that it helps to realise weighty public objectives. (Accordingly, when the relevant support and accommodations no longer serve these objectives, they ought to be revoked.)

Third, some might argue that insofar as cultural support and accommodations are a necessary remedy for any injustices that states have visited on minority cultures, then this means that, in practice, many minority cultures will be due such support and accommodations. The reason for this, they might say, is that states routinely confer unfair advantages on majority cultures and unfair disadvantages on minority cultures. Though such remedial cultural support and accommodations do not classify as multiculturalism policies as I have defined the term (see 'Multiculturalism Policies' section), they might still serve the political agenda of a large proportion of multiculturalists.

My response is that when states are simply guilty of having bestowed unfair benefits on majority cultures, then this will not justify costly support and accommodations for members of minority cultures with cultural conceptions of the good, given that citizens with subcultural and individualistic conceptions will have also suffered injustice in such cases. Since extending costly support and accommodations to the latter is likely to be prohibitively expensive (see 'The Discrimination Objection' section), the best thing to do is not to compensate any group. It is only when states have stigmatised and oppressed minority cultures specifically that these groups might be due costly remedial support and accommodations. For this to be the case, two conditions must obtain. First, the injustices must not have been rectified or superseded. ${ }^{4}$ Second, there should not be better alternative ways of addressing the injustices, such as exclusively providing minority cultures with financial support and/or educational and employment opportunities. How often these conditions are satisfied in practice is a topic for another occasion, however.

Acknowledgements I would like to thank Rainer Bauböck for helpful comments.

Funding My research is supported by an international postdoctoral fellowship (2018-00679) from the Swedish Research Council.

\section{Compliance with Ethical Standards}

Conflict of interest The author declares that there is no conflict of interest.

\footnotetext{
${ }^{4}$ For a defence of the possibility of superseding historic injustice, see Waldron (1992). For criticism, see Nine (2008).
} 
Open Access This article is distributed under the terms of the Creative Commons Attribution 4.0 International License (http://creativecommons.org/licenses/by/4.0/), which permits unrestricted use, distribution, and reproduction in any medium, provided you give appropriate credit to the original author(s) and the source, provide a link to the Creative Commons license, and indicate if changes were made.

\section{References}

Barry, B. 2002. Culture and equality: An egalitarian critique of multiculturalism. Cambridge, MA: Harvard University Press.

Bauböck, R. 2017. Unequal but fair? Cultural recognition and self-government rights. Critical Review of International Social and Political Philosophy 20 (1): 8-22. https://doi.org/10.1080/13698 230.2016.1253146.

Cohen, G. A. 1999. Expensive tastes and multiculturalism. In Multiculturalism, liberalism and democracy, ed. R. Bhargava and R. Sudarshan, 80-100. New Delhi: Oxford University Press.

Kramer, M. H. 2017. Liberalism with excellence. Oxford: Oxford University Press.

Kukathas, C. 2012. Exit, freedom and gender. In On exit, ed. D. Borchers and A. Vitikainen, 34-56. Berlin, Boston: De Gruyter.

Kymlicka, W. 1991. Liberalism, community and culture. Oxford: Clarendon Press.

Kymlicka, W. 1995. Multicultural citizenship: A liberal theory of minority rights. Oxford: Clarendon Press.

Kymlicka, W. 2018. Liberal multiculturalism as a political theory of state-minority relations. Political Theory 46 (1): 81-91. https://doi.org/10.1177/0090591717696021.

Levy, J. T. 2000. The multiculturalism of fear. Oxford: Oxford University Press.

Lippert-Rasmussen, K. 2017. Dispositional neutrality and minority rights. Critical Review of International Social and Political Philosophy 20 (1): 49-62. https://doi.org/10.1080/13698230.2016.1253162.

Martin, N. 2017. Conceptions of the good, rivalry, and liberal neutrality. Critical Review of International Social and Political Philosophy 20 (2): 143-162. https://doi.org/10.1080/13698230.2015.1110444.

Modood, T. 2013. Multiculturalism, 2nd edn. Cambridge: Polity Press.

Nine, C. 2008. Superseding historic injustice and territorial rights. Critical Review of International Social and Political Philosophy 11 (1): 79-87. https://doi.org/10.1080/13698230701880513

Orgad, L. 2015. The cultural defense of nations: A liberal theory of majority rights. Oxford: Oxford University Press.

Parekh, B. 2006. Rethinking multiculturalism, 2nd edn. Basingstoke: Palgrave Macmillan.

Patten, A. 2014. Equal recognition: The moral foundations of minority rights. Princeton, NJ: Princeton University Press.

Pierik, R., and W. Van der Burg. 2014. What is neutrality? Ratio Juris 27 (4): 496-515. https://doi. org/10.1111/raju.12057.

Raz, J. 1988. The morality of freedom. Oxford: Oxford University Press.

Réaume, D. G. 2017. Fairness and equal recognition. Critical Review of International Social and Political Philosophy 20 (1): 63-74. https://doi.org/10.1080/13698230.2016.1253163.

Scheffler, S. 2007. Immigration and the significance of culture. Philosophy \& Public Affairs 35 (2): 93-125. https://doi.org/10.1111/j.1088-4963.2007.00101.x.

Schutter, H. D. 2017. Two principles of equal language recognition. Critical Review of International Social and Political Philosophy 20 (1): 75-87. https://doi.org/10.1080/13698230.2016.1253166.

Shachar, A. 2001. Multicultural jurisdictions: Cultural differences and women's rights. Cambridge: Cambridge University Press.

Taylor, C. 1994. The politics of recognition. In Multiculturalism: Examining the politics of recognition, Expanded Paperback edn, ed. A. Gutmann, 25-73. Princeton, NJ: Princeton University Press.

Waldron, J. 1991. Minority cultures and the cosmopolitan alternative. University of Michigan Journal of Law Reform 25: 751.

Waldron, J. 1992. Superseding historic injustice. Ethics 103 (1): 4-28.

Publisher's Note Springer Nature remains neutral with regard to jurisdictional claims in published maps and institutional affiliations. 